\title{
Index to Volume 70
}

\section{ARTICLES}

ABRAMITZKY, RAN, ZEPHYR FRANK, AND APRAJIT MAHAJAN, Risk, Incentives, and Contracts: Partnerships in Rio de Janeiro, 1870-1891 ................686

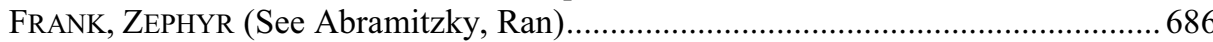

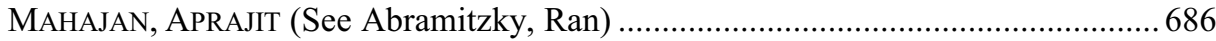

ANDRABI, TAHIR, AND MichaEL KUEHLWEIN, Railways and Price

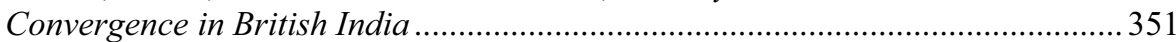

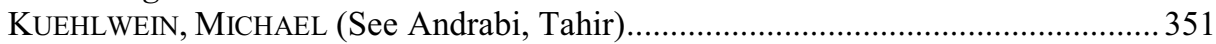

BRAINERD, ELIZABETH, Reassessing the Standard of Living in the Soviet Union: An Analysis Using Archival and Anthropometric Data Development, 18801930.

BROADBERRY, STEPHEN, AND CARSTEN BURHOP, Real Wages and Labor

Productivity in Britain and Germany, 1871-1938: A Unified Approach

to the International Comparison of Living Standards ............................................ 400

BURHOP, CARSTEN (See Broadberry, Stephen) ........................................................ 400

BURHOP, CARSTEN, The Transfer of Patents in Imperial Germany ........................... 921

CANADAY, NEIL, AND CHARLES REBACK, Race, Literacy, and Real Estate

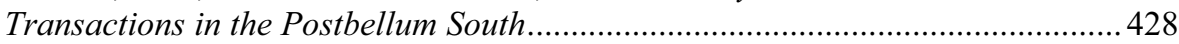

REBACK, CHARLES (See Canaday, Neil) ................................................................. 428

Costa, Dora L., Pensions and Retirement Among Black Union Army

Veterans

Daudin, Guillaume, Domestic Trade and Market Size in Late-Eighteenth-

Century France.

DREliCHMAN, MAURICIO, AND HANS-JOACHIM Voth, The Sustainable Debts of Philip II: A Reconstruction of Castile's Fiscal Position, 1566-1596. 813

VOTH, HANS-JOACHIM (See Drelichman, Mauricio)

EICHENGReEn, BARRY, AND Douglas A. IRwIN, The Slide to Protectionism in

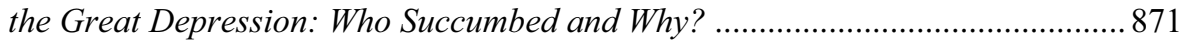

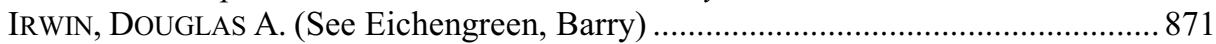

ELTIS, DAVID, FRANK D. LEWIS, AND KIMBERLY MCINTYRE, Accounting for the Traffic in Africans: Transport Costs on Slaving Voyages....................................... 940

LEWIS, FRANK D. (See Eltis, David) ..................................................................... 940

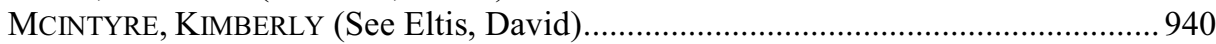

FIELD, AleXANDER J., The Procyclical Behavior of Total Factor Productivity

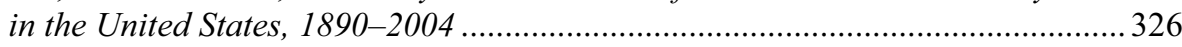

FoHLIN, CAROLINE, Asymmetric Information, Market Power, and the Underpricing of New Stock Issues in Germany, 1882-1892.

Go, Sun, AND PETER Lindert, The Uneven Rise of American Public Schools to 1850

LINDERT, PETER (See Go, Sun).

GRUBB, FARLEY, Testing for the Economic Impact of the U.S. Constitution:

Purchasing Power Parity Across the Colonies versus Across the States, 1748-1811

Huberman, Michael, AND CHRISTOPHER M. MEISSNER, Riding the

Wave of Trade: The Rise of Labor Regulation in the Golden Age of Globalization

MEISSNER, CHRISTOPHER M., (See Huberman, Michael) 
Karaman, K. KIVANÇ, AND ŞEVKet PAMUK, Ottoman State Finances in European Perspective, 1500-1914 593

PAMUK, ŞEVKET (See Karaman, K. Kivanç). 593

LAMPE, RYAN, AND PETRA MOSER, Do Patent Pools Encourage Innovation? Evidence from the Nineteenth-Century Sewing Machine Industry 898

MOSER, PETRA (See Lampe, Ryan) 898

Lanning, Jonathan A., Productivity, Discrimination, and Lost Profits During Baseball's Integration 964

Lehmann, SibyLle H., The German Elections in the 1870s: Why Germany Development Turned from Liberalism to Protectionism. 146

Lo, SHIH-TSE, AND DHANOOS SUTTHIPHISAL, Crossover Inventions and Knowledge Diffusion of General Purpose Technologies: Evidence from the Electrical Technology.....

SUTTHIPHISAL, DHANOOS (See Lo, Shih-Tse) ......................................................... 744

Mitchener, KRIS JAMES, MASATO SHIZUME, AND MARC D.WEIDENMIER, Why

Did Countries Adopt the Gold Standard? Lessons from Japan ...............................2. 27

SHIZUME, MASATO (See Mitchener, Kris James) ......................................................... 27

WEIDENMIER, MARC D. (See Mitchener, Kris James) ................................................... 27

Neumann, Todd C., Price V. Fishback, And Shawn Kantor, The Dynamics of Relief Spending and the Private Urban Labor Market During the New Deal ....

FISHBACK, PRICE V. (See Neumann, Todd C.).

KANTOR, SHAWN (See Neumann, Todd C.)

NiCHOLAS, TOM, The Role of Independent Invention in U.S. Technological Development, 1880-1930

Ogilvie, Sheilagh, Consumption, Social Capital, and the "Industrious

Revolution" in Early Modern Germany.

Rose, Jonathan D., Hoover's Truce: Wage Rigidity in the Onset of the Great Depression.

Roy, TIRTHANKAR, Economic Conditions in Early Modern Bengal: A Contribution to the Divergence Debate

SÁNCHEZ, FABIO, MARÍA DEL PILAR LÓPEZ-URIBE, AND ANTONELla FAZIO, Land Conflicts, Property Rights, and the Rise of the Export Economy in Colombia, 1850-1925.

Del PILAR LÓPEZ-URIBE, MARÍA (See Sánchez, Fabio)

FAZIO, ANTONELla (See Sánchez, Fabio)

SAXONHOUSE, GARY R., AND GAVIN WRIGHT, National Leadership and

Competing Technological Paradigms: The Globalization of Cotton Spinning, 1878-1933

WRIGHT, GAVIN (See Saxonhouse, Gary R.)

SNOWden, Kenneth A., Covered Farm Mortgage Bonds in the United States During the Late Nineteenth Century....

STECKEL, RICHARD H., Inequality Amidst Nutritional Abundance: Native Americans on the Great Plains

\section{NOTES, DISCUSSION, DISSERTATION SUMMARIES, POSTER PRESENTATIONS, AND REVIEW ARTICLES}

Bowblis, JoHn R., The Decline in Infant Death Rates, 1878-1913: The Role of Early Sickness Insurance Programs. 
BroAdBerry, StePhen, Comments on Slavin, Studer, and Yan 472

CAMPBell, Douglas, History, Culture, and Trade: A Dynamic Gravity Approach

CARTER, LINDA K., Evening Schools and Child Labor in the United States, $1870-1910$

COCHRANE, SARAH, Examining the Impact of World War I on the City of

London

EASTERly, MiCHAel, Your Job is Your Credit: Creating a Market for Loans to

Salaried Employees in New York City, 1885-1920

ELI, SHARI, Income Effects on Late-Life Health: Evidence from Union Army Pensions.....

KOYAMA, MARK, The Demise of the Backwards Bending Labor Supply Curve ....... 500

LI, KWAN LEUNG, Commerce and the Initial Rise of Wall Street ............................... 503

Miller, MELINDA, Essays on Race and the Persistence of Economic Inequality..... 468

MuRRAY, JoHN E., Comments on Carter, Easterly, and Miller .................................. 476

OSKAR, GLENDA, The Adoption of Radio Technology in the United States ................ 502

SALEH, MOHAMMED, Historical Origins of Inter-Religion Differences:

Evidence from Nineteenth- and Twentieth-Century Egypt....

SANTAROSA, VERONICA AOKI, Mitigating Asymmetric Information in Early

Modern Financial Markets: The Bill of Exchange and the Role of the Joint-

Liability Rule

SLAVIN, PHILIP, Feeding the Brethren: Grain Provisioning of Norwich Cathedral Priory, c. 1280-1370....

Sng, TuAn HweE, Agency Problem and Dynastic Decline: A Study of Late Imperial China, 1700-1850

STUDER, ROMAN, Market Integration and Economic Development: A Comparative Study of India and Europe, 1700-1900

TURUnEN, OLli, From Intangible Capital to Institutional Agencies: The Ideas of Human and Social Capital and Their Demise in German Historical Economics....

Vechbanyongratana, Jessica, Personal Savings in Nineteenth-Century

America

WJUNISKI, BERNARDo STUHLBERGER, Education and Development Projects in Brazil, 1933-2008: A Political Economy Perspective...

YAN, SE, Real Wages and Wage Inequality in China, 1858-1936

YU, YI-WEN, Corporate State or State Incorporate: The Modern/Capitalistic

State-Building in the Low Countries, Britain, China, and Japan .502

ZEITZ, PETER, Do Local Institutions Affect All Foreign Direct Investors in the Same Way? Evidence from the Interwar Chinese Textile Industry..... 500

\section{ABSTRACTS OF PAPERS PRESENTED AT THE ANNUAL MEETING}

Allen, SAM, State Variation in Workers' Compensation Insurance: A Political Economy of Benefits, 1930-2000

BEAN, JESSICA, Poverty and Women's Work in Interwar London

BOUSTAN, LEAH PlatT, RAN ABRAMITZKY, AND KATHERINE ERIKSSON, Europe's

Tired, Poor, Huddled Masses: Self-Selection and Economic Outcomes in the Age of Mass Migration.

ABRAMITZKY, RAN (See Boustan, Leah Platt) 
ERIKSSON, KATHERINE (See Boustan, Leah Platt) 488

BURNETTE, JOYCE, The Emergence of Wage Discrimination in U.S. Manufacturing

CALOMIRIS, CHARLES, LEE OHANIAN, J. BRADFORD DELONG, RICHARD SYLLA, AND RICHARD H. STECKEL, Financial Crises: Lessons from the Past for the Present 493

OHANIAN, LEE (See Calomiris, Charles)

DELONG, J. BRADFORD (See Calomiris, Charles)

SYLLA, RICHARD (See Calomiris, Charles)

STECKEL, RiCHARD H. (See Calomiris, Charles)

ChANEY, ERIC, Sultans, the Shariah, and Seven Empty Ears: Economic

Catastrophes, Religion, and Institutional Change.

Chaudhary, LatiKa, AND Dan Bogart, Public-Private Partnerships and Efficiency: A Historical Perspective from Indian Railways....

BOGART, DAN (See Chaudhary, Latika) 486

ClAy, KAREN, Dynamic Effects of Legal Origins: Evidence from the American States.....

COLlins, William J., AND KATHARINE L. SHESTER, Slum Clearance and Urban Renewal in the United States, 1949-1974

SHESTER, KATHARINE L. (See Collins, William J.)....

CoOK, LISA D., A Green Light for Red Patents? Outsourcing Patent Protection in the Soviet Union and Russia, 1971-2007

CufF, ТімотнY, Biological Welfare Change and Variation in Mid-to LateNineteenth-Century Pennsylvania: Evidence from the Stature of the Pennsylvania National Guard.

Dobado-GonZalez, RAFAEL, AND HeCtor GARCIA, Neither So Low nor So

Short! Wages and Heights in Late Colonial Latin America in Comparative Perspective.

GARCIA, HECTOR (See Dobado-Gonzalez, Rafael) 484

DURAN, XAVIER, Was the First Transcontinental Railroad Built Ahead of Demand? Evidence from Entrepreneurial Expectations and an Empirical Entry Decision Model ....

FENSKE, JAMES, Land Abundance and Economic Institutions: Egba Land and Slavery, 1830-1914

FERnANDES, FeliPE TAMEGA, Stretching the Inelastic Rubber: Taxation,

Welfare, and Lobbies in Amazonia, 1870-1910

FritsCHER, ANDRE C., AND Aldo MusACCHIO, Can Endowments Explain Regional Inequality? State Governments and the Provision of Public Goods in Brazil, 1889-1930

MusACCHIO, Aldo (See Fritscher, Andre C.)

GreENBAUM, JEFFreY, Land Endowments, Child Labor, and the Development of Public Schooling: Evidence from the Early Twentieth-Century United States.....

Hanley, ANNe, Pests and Pestilence: Belle Époque Brazil.

HANSEN, ZEYNEP K., AND SCOTT E. LOWE, Climate Variability and Water Infrastructure: Historical Experience in the Western United States

LOWE, SCOTT E. (See Hansen, Zeynep K.).....

Hennessey, JessicA, The Adoption of Constitutional Home Rule: A Test of Endogenous Policy Decentralization. 
Huberman, Michael, AND CHRISTOPHER MEISSNER, Riding the Wave of

Trade: Explaining the Rise of Labor Regulation in the Golden Age of

Globalization

MEISSNER, CHRISTOPHER (See Huberman, Michael)

INWOOD, KRIS, AND OLIVER MASAKURE, Inequality and Physical Well-Being

Among Colored and White Men in the Cape Colony Before 1900

MASAKURE, OLIVER (See Inwood, Kris).

KEPINSKA, EWA, AND ODED STARK, The Evolution and Sustainability of

Seasonal Migration from Poland to Germany: How It Came into Being, and

How and Why It Has Survived the Passage of Time

STARK, ODED (See Kepinska, Ewa)....

KHAN, ZorINA, Promoting the Useful Arts: An Empirical Estimation of

Technological Innovation Outside the Patent System, 1790-1880.....

KIM, DUOL, AND HEEJIN PARK, Measuring Living Standard from the Lowest:

Height of the Haengryu Deceased in Colonial Korea

PARK, HEEJIN (See Kim, Duol).

KITSIKOPOULOS, HARRY, Land Productivity and Standards of Living in

Medieval England, 1200-1500

Komlos, JoHn, A Quarter-Century of Research on the Antebellum Puzzle

LIBECAP, GARY, AND DEAN LUECK, The Demarcation of Land and the Role of Coordinating Institutions

LUECK, DEAN (See Libecap, Gary)

Mensink, Julia, The Unexpected Developments of the U.S. Poverty

Thresholds: Production, Distribution, and Usage Since 1963

Michel, SANDRINE, AND DelPhInE VAllade, The Funding of Social Expenditures and Long-Term Economic Growth: The Contribution of a Synthetic Indicator of the Historical Human Development. The Case of

France from the Mid-Nineteenth Century to the Present Day

VALlade, DelPhINE (See Michel, Sandrine)

Moehling, Carolyn, And Melissa Thomasson, The Political Economy of

Saving Mothers and Babies

THOMASSON, MELISSA (See Moehling, Carolyn).....

Morgan, StePHEN L., Adjustment of Age-Related Height Shrinkage in

Archival Data for Chinese: A Post Hoc Longitudinal Survey....

MORIGUCHI, CHIAKI, Child Adoption in the United States, 1880-1930: New

Evidence from IPUMS

Moser, PETRA, Compulsory Licensing: Evidence from the Trading with the

Enemy Act

PARMAN, JoHn, Childhood Health and Human Capital Formation: New

Evidence from Genetic Brothers in Arms.

Rosenbloom, Joshua L., Thomas Weiss, and Peter C. MANCALl, The

Standard of Living in the Colonies and States of the Middle Atlantic Region

Before 1800: Evidence from a Sample of Widows' Allowances

WEISS, THOMAS (See Rosenbloom, Joshua L.)

MANCALl, PETER C. (See Rosenbloom, Joshua L.)....

Voth, HANS-JoaChIM, AND Jonathan Hersh, Sweet Diversity: Colonial

Goods and the Rise of European Living Standards After 1492

HERSH, JONATHAN (See Voth, Hans-Joachim)

WALDENSTROM, DANIEL, JESPER RoINE, AND JONAS Vlachos, The Long-Run

Determinants of Inequality: What Can We Learn from Top Income Data? 
ROINE, JESPER (See Waldenstrom, Daniel)

VlaCHOS, JONAS (See Waldenstrom, Daniel).

WINDER, GORDON M., The Urban Penalty: Stature Within the U.S. Urban

System, 1850-1880

Yoo, Dongwoo, Health in the Nineteenth Century Through the Lens of

Geographically Weighted Regression.

ZehetMayer, Matthias, The Postbellum Continuation of the Antebellum Puzzle.

\section{REVIEWS OF BOOKS}

ALLEn, ROBERT, The British Industrial Revolution in Global Perspective

Bell, ANDREw McIlwaIne, Mosquito Soldiers: Malaria, Yellow Fever, and the Course of the American Civil War.

BIRLA, RITU, Stages of Capital: Law, Culture, and Market Governance in Late Colonial India.

Cheung, SuI-WAI, The Price of Rice: Market Integration in Eighteenth-Century China

Dal Lago, Enrico, And Constantina Katsari, EdS., Slave Systems: Ancient and Modern

KATSARI, CONSTANTINA (See Dal Lago, Enrico, Ed.)

DAMUs, SYlVESTER, Argentine Railways: Seven Papers on Their Economics and History

DATTEL, GENE, Cotton and Race in the Making of America: The Human Costs of Economic Power.

DE BRUYN KoPS, HeNRIETTE, Japanese Economic Development: Markets, Norms, Structures

DEE, DARRYL, Expansion and Crisis in Louis XIV's France: Franche-Comté and Absolute Monarchy, 1674-1715

DIAMOND, JARED, AND JAMES A. ROBINSON, EDS., Natural Experiments in History

ROBINSON, JAMES A. (See Diamond, Jared, Ed.)

EICHENGREEN, BARRY, Global Imbalances and the Lessons of Bretton Woods ........ 259

EPSTEIn, STEVEn A., An Economic and Social History of Later Medieval Europe, 1000-1500.

EvANS, CHRIS, AND GÖRAN RYDÉN, Baltic Iron in the Atlantic World in the Eighteenth Century

RYDÉN, GÖRAN (See Evans, Chris)

FISCHEL, William A., Making the Grade: The Economic Evolution of American School Districts....

FRANCKS, PENELOPE, The Japanese Consumer: An Alternative History of Modern Japan 1006

GelBer, StEven M., Horse Trading in the Age of Cars: Men in the Marketplace

HANAWALT, BARBARA A., The Wealth of Wives: Women, Law, and Economy in Late Medieval London.

HANCOCK, DAVID, Oceans of Wine: Madeira and the Emergence of American Trade and Taste

KARP, JonATHAN, The Politics of Jewish Commerce: Economic Thought and Emancipation in Europe, 1638-1848 
Kohama, Hirohisa, Industrial Development in Postwar Japan .254

KUZMER, KenNeth L., AND Joe W. TrotTER, EDS., African American Urban History Since World War II

TrotTER, Joe W. (See Kuzmer, Kenneth L., Ed.) .526

LAINS, PEDRO, AND ViCENTE PINILLA, EDS., Agriculture and Economic Development in Europe Since 1870 .

PinILla, Vicente (See Lains, Pedro, Ed.)

Landes, David S., Joel MoKyr, AND William J. Baumol, Eds., The Invention of Enterprise: Entrepreneurship from Ancient Mesopotamia to Modern Times.... 772

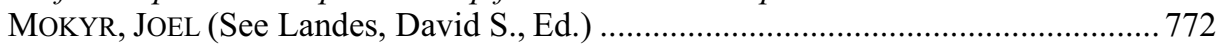

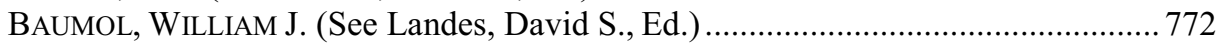

LARSON, JOHN LAURITZ, The Market Revolution in America: Liberty, Ambition, and the Eclipse of the Common Good.

LI, LiLlian M., Fighting Famine in North China: State, Market, and Environmental Decline, 1690s-1990s

LyONS, JOHN S., LOUIS P. CAIN, AND SAMUEL H. WILLIAMSON, EDS., Reflections on the Cliometrics Revolution: Conversations with Economic Historians ............ 769

CAIN, LoUIS P. (See Lyons, John S., Ed.) ................................................................... 769

WILLIAMSON, SAMUEL H. (See Lyons, John S., Ed.) ……........................................ 769

MALONE, PATRICK M., Waterpower in Lowell: Engineering and Industry in Nineteenth-Century America

MiLlER, STEPHEN, State and Society in Eighteenth-Century France: A Study of

Political Power and Social Revolution in Languedoc

MOKYR, JOEL, The Enlightened Economy: An Economic History of Britain, $1700-1850$

Murmann, JOHAN PETER, Knowledge and Competitive Advantage: The Coevolution of Firms, Technology, and National Institutions

MusACCHIO, ALDO, Experiments in Financial Democracy: Corporate Governance and Financial Development in Brazil, 1882-1950

NORTH, DOUGLASS C., JOHN JOSEPH WALlIS, AND BARRY R.WEINGAST, Violence and Social Orders: A Conceptual Framework for Interpreting Recorded Human History

WALLIS, JOHN JOSEPH (See North, Douglass C.)

WEINGAST, BARRY R. (See North, Douglass C.)

NUSSDORFER, LAURIE. Brokers of Public Trust: Notaries in Early Modern Rome

Ó GRÁDA, CORMAC, Jewish Ireland in the Age of Joyce: A Socioeconomic History

PEDEN, G. C., Arms, Economics, and British Strategy: From Dreadnoughts to Hydrogen Bombs.

PINCUS, STEVE, 1688: The First Modern Revolution

PREDA, ALEX, Framing Finance: The Boundaries of Markets and Modern Capitalism

Puffert, Douglas J., Tracks Across Continents, Paths Through History: The

Economic Dynamics of Standardization in Railway Gauge

Quiroz, Alfonso W., Corrupt Circles: A History of Unbound Graft in Peru ........ 1008

REINHART, CARMEN, AND KENNETH Rogoff, This Time is Different: Eight

RogOFF, KeNNETH (See Reinhart, Carmen) 
Schoen, Brian, The Fragile Fabric of Union: Cotton, Federal Politics, and the Global Origins of the Civil War. .252

THOMPSON, Ross, Structures of Change in the Mechanical Age:

Technological Innovation in the United States, 1790-1865 778

WALKer, JULIET E. K., The History of Black Business in America: Capitalism, Race, Entrepreneurship, Volume 1, to 1865 (Second Edition) 777

WATERMAn, KEES-JAN, ED., "To Do Justice to Him and Myself": Evert Wendell's Account Book of the Fur Trade with Indians in Albany, New York, 1695-1726... 


\section{Contributors}

(a) $=$ Articles.

(b) = Notes, discussions, review articles, poster presentations, and dissertation summaries.

(c) $=$ Reviews of books.

(d) = Abstracts of papers presented at the annual meeting.

Abramitzky, R., 686(a), 488(d)

Allen, R. C., 900(a)

Allen, S., 491(d)

Andrabi, T., 351(a)

Bean, J., 495(d)

Bell, A., 995(c)

Bogan, V., 777(c)

Bogart, D., 486(d), 1010(c)

Boustan, L. P., 488(d), 526(c)

Bowblis, J. R., 221(b)

Brainerd, E., 83(a)

Bredefeldt, R., 517(c)

Broadberry, S., 400(a), 472(b)

Burhop, C., 400(a), 921(a)

Burnette, J., 491(d)

Calomiris, C., 493(d)

Campbell, D., 500(b)

Canaday, N., 428(a)

Carlos, A. M., 525(c)

Carter, L. K., 458(b)

Chaney, E., 488(d)

Chaudhary, L., 486(d)

Clay, K., 490(d)

Cochrane, S., 501(b)

Coclanis, P. A., 1000(c)

Collins, W. J., 485(d)

Cook, L. D., 494(d)

Costa, D. L., 567(a)

Cuff, T., 484(d)

Daudin, G., 716 (a)

Del Pilar López-Uribe, M., 378(a)

Delong, J. B., 493(d)

Deng, K. G., 1005(c)

Dobado-Gonzalez, R., 484(d)

Drelichman, M., 813(a)

Duran, X., 487(d)

Easterly, M., 458(b)

Eichengreen, B., 871(a)

Eli, S., 499(b)

Eloranta, J., 998(c)
Eltis, D., 940(a)

Epstein, S. A., 515(c)

Eriksson, K., 488(d)

Fazio, A., 378(a)

Fenske, J., 490(d)

Fernandes, F. T., 486(d)

Field, A. J., 326(a)

Fishback, P. V., 195(a)

Fohlin, C., 630(a)

Frank, Z., 686 (a)

Fritscher, A. C., 496(d)

Garcia, H., 484(d)

Garnham, N., 249(c)

Go, S., 1(a), 1003(c)

Goldstone, J., 993(c)

Greenbaum, J., 497(d)

Grubb, F., 118(a)

Gupta, B., 521(c)

Hanley, A., 486(d)

Hansen, Z. K., 483(d)

Hennessey, J., 490(d)

Hersh, J., 495(d)

Hilt, E., 780(c)

Hohenberg, P. M., 247(c)

Huberman, M., 657(a), 491(d)

Inwood, K., 487(d)

Irwin, D. A., 871(a)

Kantor, S., 195(a)

Karaman, K. K., 593(a)

Kepinska, E., 489(d)

Khan, Z., 494(d)

Kiewiet, D. R., 255(c)

Kim, D., 488(d)

Kitchens, C., 1002(c)

Kitsikopoulos, H., 493(d)

Klein, M., 532(c)

Komlos, J., 493(d)

Koyama, M., 500(b)

Kuehlwein, M., 351(a)

Lampe, R., 898(a) 
Lanning, J. A., 964(a)

Lehmann, S. H., 146(a)

Lewis, F. D., 940(a)

Li, K. L., 503(b)

Libecap, G., 483(d)

Liebowitz, J. J., 996(c)

Lindert, P., 1(a)

Lo, S.-T., 744(a)

Lowe, S. E., 483(d)

Lueck, D., 483(d)

Mahajan, A., 686 (a)

Mancall, P. C., 485(d)

Margo, R. A., 770(c)

Masakure, O., 487(d)

McCants, A. E. C., 775(c)

McIntyre, K., 940(a)

Meissner, C. M., 657(a), 491(d)

Mensink, J., 497(d)

Metzler, M., 254(c)

Michel, S., 498(d)

Miller, M., 468(b)

Miller, S., 509(c)

Mitchener, K. J., 27(a)

Moehling, C., 483(d)

Mokyr, J., 510(c)

Morgan, S. L., 492(d)

Moriguchi, C., 489(d)

Moser, P., 494(d), 898(a)

Musacchio, A., 496(d)

Neal, L., 260(c)

Neumann, T., 250(c)

Nicholas, T., 57(a)

Ogilvie, S., 287(a)

Ohanian, L., 493(d)

Olmstead, A. L., 778(c)

Oskar, G., 502(b)

Pamuk, S., 593(a)

Park, H., 488(d)

Parman, J., 496(d)

Ramseyer, J. M., 1006(c)

Reback, C., 428(a)

Roine, J., 498(d)

Rose, J. D., 843(a)

Rosenbloom, J. L., 485(d)

Rosenthal , J.-L., 242(c)

Rössner, P. R., 773(c)

Roy, T., 179(a)

Saleh, M., 503(b)

Sánchez, F., 378(a)
Santarosa, Veronica Aoki, 499(b)

Saxonhouse, G. R., 535(a)

Shester, K. L., 485(d)

Shiue, C., 523(c)

Shizume, M., 27(a)

Slavin, Philip, 446(b)

Sng, T. H., 501(b)

Snowden, K. A., 783(a)

Stark, O., 489(d)

Steckel, R. H., 265(a), 493(d)

Studer, R., 450(b)

Surdam, D. G., 252(c)

Sutherland, D. M. G., 245(c)

Sutthiphisal, D., 744(a)

Sylla, R., 493(d)

Tell, F., 530(c)

Temin, P., 772(c)

Thomasson, M., 483(d)

Thomson, R., 529(c)

Toniolo, G., 259(c)

Triner, G. D., 519(c)

Turunen, O., 502(b)

Vallade, D., 498(d)

Vechbanyongratana, J., 499(b)

Velkar, A., 262(c)

Vizcarra, C., 1008(c)

Vlachos, J., 498(d)

Voth, H.-J., 495(d), 813(a)

Waldenstrom, D., 498(d)

Weidenmier, M. D., 27(a), 766(c)

Weiss, T., 485(d)

Whaples, R., 769(c)

Winder, G. M., 492(d)

Wjuniski, B. S., 501(b)

Wright, G., 535(a)

Yan, S., 454(b)

Yoo, D., 497(d)

Yu, Y.-W., 502(b)

Zehetmayer, M., 482(d)

Zeitz, P., 500(b) 


\section{CAMBRIDGE}

\section{Outstanding Titles from Cambridge!}

\section{Textbook!}

The Cambridge Economic History of Modern Europe

Stephen BroadberRy And KeVIn H. O'Rourke

The Cambridge Economic History of Modern Europe

Volume 1: 1700-1870

\$110.00: Hb: 978-0-521-88202-6: $368 \mathrm{pp}$ \$40.00: Pb: 978-0-521-70838-8

Volume 2: 1870 to the Present \$110.00: Hb: 978-0-521-88203-3: $480 \mathrm{pp}$. $\$ 40.00: \mathrm{Pb}: 978-0-521-70839-5$

\section{Textbook!}

An Economic

History of Europe

Knowledge, Institutions and Growth, 600 to the Present

Karl Gunnar Persson

New Approaches to Economic and Social History

\$85.00: Hb: 978-0-521-84009-5: $270 \mathrm{pp}$. \$32.99: Pb: 978-0-521-54940-0

Commerce before Capitalism in Europe, 1300-1600

Martha C. Howell

\$90.00: Hb: 978-0-521-76046-1: $366 \mathrm{pp}$. \$29.99: Pb: 978-0-521-14850-4

Now in Paperback!

Capitals of Capital

The Rise and Fall

of International

Financial Centres 1780-2009

YousSEF CASSIS

Translated by Jacqueline Collier \$32.99: Pb: 978-0-521-14404-9: 408 pp.

\section{Fixed Ideas of Money}

Small States and Exchange Rate

Regimes in Twentieth Century Europe

Tobias Straumann

Studies in Macroeconomic History \$90.00: Hb: 978-0-521-11271-0: 312 pp.

The Reinterpretation of Italian Economic History From Unification to the Great War Stefano Fenoaltea

\$85.00: Hb: 978-0-521-19238-5: 220 pp.

From Artisan to Worker

Guilds, the French State, and the Organization of Labor, 1776-1821

Michael P. Fitzsimmons

\$95.00: Hb: 978-0-521-19376-4: 304 pp.

\section{Agrarian Reform}

in Russia

The Road from Serfdom

CAROL LEONARD

\$90.00: Hb: 978-0-521-85849-6: 287 pp.

Now in Paperback!

West Indian Slavery and British Abolition, 1783-1807

DAVID BECK RYden

\$27.99: Pb: 978-0-521-14804-7: 350 pp.

The Capital and the Colonies

London and the Atlantic Economy 1660-1700

Nuala Zahedieh

\$95.00: Hb: 978-0-521-51423-1: 360 pp.
Cambridge Studies in Economic History - Second Series

Childhood and Child Labour in the British Industrial Revolution

JANE HUMPHRIES

\$99.00: Hb: 978-0-521-84756-8: 480 pp.

Making the Market

Victorian Origins of

Corporate Capitalism

PAUL JOHNSON

\$95.00: Hb: 978-0-521-85783-3: 266 pp.

The Decline of Sterling

Managing the Retreat of an International Currency, 1945-1992

Catherine R. Schenk

\$99.00: Hb: 978-0-521-87697-1: 456 pp.

Government and Markets Toward A New Theory of Regulation Edited by EdWARd Balleisen AND DAVID Moss

\$50.00: Hb: 978-0-521-11848-4: 576 pp.

Now in Paperback!

The World's Newest Profession Management Consulting in the Twentieth Century

Christopher D. McKenna

Cambridge Studies in the Emergence of Global Enterprise

\$23.99: Pb: 978-0-521-75759-1: 392 pp.

Byzantine Jewry in the Mediterranean Economy JosHuA HoLO

\$99.00: Hb: 978-0-521-85633-1: 298 pp. Prices subject to change. 


\section{Inside the Nixon Administration The Secret Diary of Arthur Burns, 1969-1974 Edited by Robert $\mathrm{H}$. Ferrell}

"Provides invaluable insights into the inner workings of the Nixon administration, the economic issues it confronted, and the fascinating and strange character of Nixon himself."-Wyatt C. Wells, author of Economist in an Uncertain World: Arthur F. Burns and the Federal Reserve, 1970-78 160 pages, 14 photos, Cloth $\$ 24.95$

\section{A Most Magnificent Machine America Adopts the Railroad, 1825-1862} Craig Miner

"Miner's lively account offers unprecedented insight into the exhilaration and the anxiety that accompanied this transforming innovation."

-Steven W. Usselman, author of Regulating Railroad Innovation: Business, Technology, and Politics in America, 1840-1920

352 pages, 20 illustrations, Cloth $\$ 34.95$

\section{University Press of Kansas}
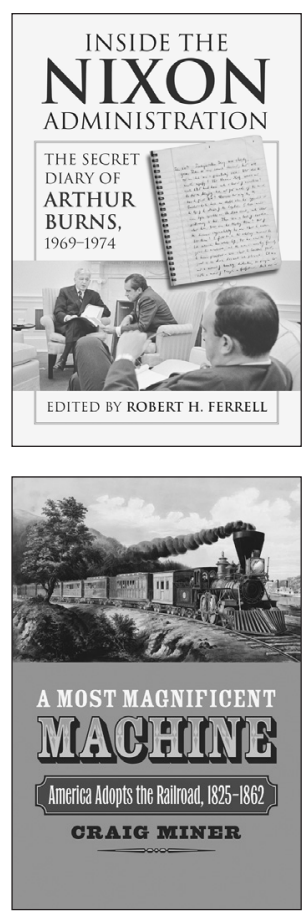


\section{CAMBRIDGE}

\section{Outstanding Titles from Cambridge!}

The History of the

Social Sciences since 1945

Roger E. BACKHOUSE and Philippe Fontaine

\$75.00: Hb: 978-0-521-88906-3: 268 pp. \$25.99: Pb: 978-0-521-71776-2

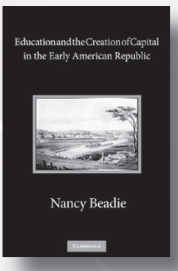

Education and the Creation of Capital in the Early American Republic

Nancy Beadie

\$95.00: Hb: 978-0-521-19628-4: 368 pp.

\section{Europe Since 1980}

IVAN T. BEREND

The World Since 1980

\$85.00: Hb: 978-0-521-11240-6: 346 pp. \$29.99: Pb: 978-0-521-12917-6

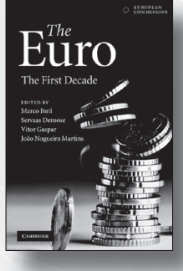

The Euro

The First Decade

Edited by MARCo Buti,

ServaAs Deroose,

VITOR GASPAR,

and JoÃo Nogueira Martins

\$175.00: Hb: 978-9-279-09842-0: 1,048 pp.

The Bank of England 1950s to 1979

ForRest CAPIE

Studies in Macroeconomic History

\$150.00: Hb: 978-0-521-19282-8: 920 pp.

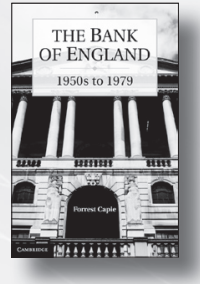

Prices subject to change.

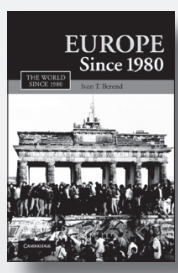

The Atlantic Slave Trade

Herbert S. Klein

New Approaches to the Americas

\$90.00: Hb: 978-0-521-76630-2: $264 \mathrm{pp}$. \$24.99: Pb: 978-0-521-18250-8
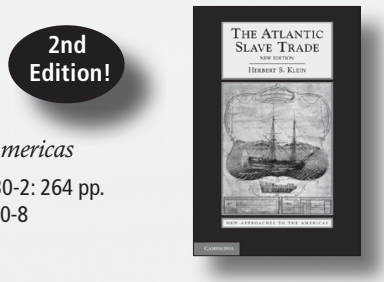

Von Neumann, Morgenstern, and the Creation of

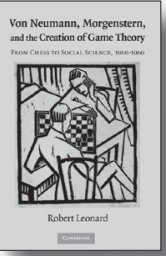
Game Theory

From Chess to Social Science, 1900-1960

ROBERT LEONARD

Historical Perspectives on

Modern Economics

\$95.00: Hb: 978-0-521-56266-9: $402 \mathrm{pp}$.

\section{State and Market in}

\section{European Union Law}

The Public and Private Spheres of the Internal Market before the EU Courts

Wolf SAuter and HARM Schepel

Cambridge Studies in

European Law and Policy

\$121.00: Hb: 978-0-521-85775-8: $270 \mathrm{pp}$

\$48.99: Pb: 978-0-521-67447-8

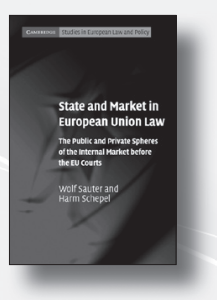




\section{The MIT Press}

\section{Reconceptualizing the Industrial Revolution \\ edited by Jeff Horn, Leonard N. Rosenband, \\ No Precedent, No Plan \\ INSIDE RUSSIA'S 1998 DEFAULT \\ Martin Gilman}

and Merritt Roe Smith

Closely linked essays examine distinctive national patterns of industrialization.

Dibner Institute Studies in the History of Science and Technology 336 pp., $\$ 40$ paper

\section{Prime Movers of Globalization}

THE HISTORY AND IMPACT OF DIESEL

ENGINES AND GAS TURBINES

\section{Vaclav Smil}

"Smil masterfully traces the technological evolution and impact of diesel engines and gas turbines, and makes a convincing case for their role as prime movers of globalization-even though these technolo-

"Those who have a stereotypical view of what has happened in Russia since the collapse of the USSR will take no comfort from reading No Precedent, No Plan. Drawing on a unique combination of experience and expertise, Martin Gilman convincingly proves that 'the reality is more complex, and perhaps more troubling.' By putting the story of Russia's struggle for a market economy in broader international and historical context, he makes an invaluable contribution to our view of these critical years in Russia." - Fyodor Lukyanov, editor, Russia in Global Affairs

416 pp., 7 illus., $\$ 29.95$ cloth gies escape public notice." - Rajan Gupta, Fellow, Los Alamos National Laboratory 264 pp., 73 illus., $\$ 29.95$ cloth 


\section{CAMBRIDGE}

\section{Winner of the Alice Hanson Jones Prize of the Economic History Association 2010}

\section{Creating Abundance}

Biological Innovation and American Agricultural Development

\section{Alan L. Olmstead, University of California, Davis}

Paul W. RhOde, University of North Carolina, Chapel Hill

"This is an important book! It traces the stream of biological innovation that over a period of two centuries has transformed the technical landscape of American agriculture. It will be the standard against which the next generation of research in the history of agricultural technology will be evaluated."

-Vernon W. Ruttan, Regents Professor Emeritus, Department of Applied Economics and Department of Economics, University of Minnesota

"In Creating Abundance Alan Olmstead and Paul Rhode examine an important, but often neglected, aspect of American economic growth over the course of several centuries. Based on extensive research in a large variety of primary and secondary sources, including numerous state and national agricultural reports and related private documents, they describe in great detail the important biological developments influencing crop and livestock productivity. This is an original and superb work of scholarship. This book should be of interest to all economic historians, historians, and agricultural economists."

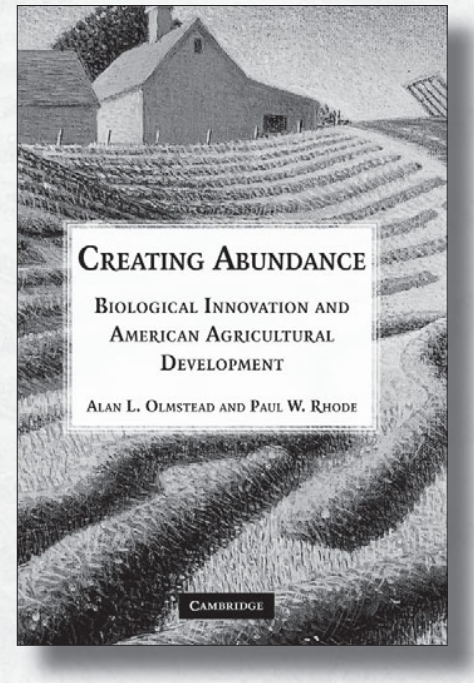

\$85.00: 978-0-521-85711-6: Hb: $480 \mathrm{pp}$ \$24.99: 978-0-521-67387-7: $\mathrm{Pb}$

-Stanley L. Engerman, John H. Munro Professor of Economics and Professor of History, University of Rochester

"In an era focusing on sustainability and climate change, Creating Abundance should be required reading for environmentalists, economists, and policy makers, as well as for economic, environmental and technological historians (and their students). The culmination of nearly two decades of extensive, patient, and inclusive research, Creating Abundance combines theoretical sophistication with a supple writing style to illuminate both a host of planning/policy advances and errors and the centrality of engaged practitioners' efforts in building flexible and responsive relationships with the natural world."

-Philip Scranton, Board of Governors Professor, History of Industry and Technology, Rutgers-Camden; Editor-in-Chief, Enterprise and Society

This book demonstrates that American agricultural development was far more dynamic than generally portrayed. In the two centuries before World War II, a stream of biological innovations revolutionized the crop and livestock sectors, increasing both land and labor productivity. Biological innovations were essential for the movement of agriculture onto new lands with more extreme climates, for maintaining production in the face of evolving threats from pests, and for the creation of the modern livestock sector. These innovations established the foundation for the subsequent Green and Genetic Revolutions. The book challenges the misconceptions that, before the advent of hybrid corn, American farmers single-mindedly invested in laborsaving mechanical technologies and that biological technologies were static.

Prices subject to change. 